\title{
BISHOP OF VOLYN ANTONIUS (KHRAPOVITSKY) AND JANUARY 9/22, 1905
}

\author{
Konstantin V. Kremenetsky \\ New York Film Academy, Riverside Drive, Burbank, California, USA
}

\begin{abstract}
British press proclaimed the murder of Grand Duke Sergius being a revenge for the "Bloody Sunday". That was an episode of anti-Russian media campaign during the Russian-Japanese war. Imperial Manifesto of February 18, 1905 contained an official statement about internal unrest and labor strikes. The sermon of bishop of Volyn Antonius (Khrapovitsky) at Isaac Cathedral of St. Petersburg on February 20, 1905 was a direct response to the Manifesto. In that sermon, Antonius also made a statement about causes of riots at the capital on January 9/22, 1905. Antonius was absent from the capital in January, but got information about the events when present in the Holy Synod in February 1905. The statement by Antonius has been seen as a confirmation of the official government evaluation of the January 9/22, 1905 riots. That was also the reason why immediately upon the publication that sermon provoked a series of media attacks on Antonius from writers associated with a "liberation movement". First responder was Vasily Rozanov, who was shortly followed by Sergey Bulgakov. For both writers, the criticism of the sermon by Antonius was directly related to their political views and loyalties to the revolutionary movement. The better-known attack on Antonius was performed by then well-known writer Dmitry Merezhkovsky in 1906-1907. Merezhkkovsky's attitude was connected first with the propaganda campaign to the election of State Duma in early 1906. Later, Merezhkovsky's interest to the subject of Antonius' sermon was linked to his stay in Paris and connections to socialists and terrorists.
\end{abstract}

Key words: $9^{\text {th }}$ January 1905, Antonius Khrapovitsky, S.N. Bulgakov, V.V. Rozanov, D.S. Merezhkovsky, liberation movement, propaganda.

УДК 94(470)

ББК 63.3

Дата поступления статьи: 25.07.2016

Дата принятия статьи: 25.11.2016

\section{ЕПИСКОП ВОЛЫНСКИЙ АНТОНИЙ (ХРАПОВИЦКИЙ) И 9/22 ЯНВАРЯ 1905 ГОДА}

\author{
Константин Владимирович Кременецкий \\ Нью-Йоркская киноакадемия, Риверсайд Драйв, Бербанк, Калифорния, США
}

\begin{abstract}
Аннотация. Убийство великого князя Сергия Александровича было использовано английской печатью как очередной повод в информационной кампании против России во время русско-японской войны. Вскоре после убийства Сергия Александровича был обнародован Манифест 18 февраля 1905 г., содержавший правительственную оценку событий начала 1905 года. В статье анализируется текст «Слова о Страшном суде и о современных событиях» епископа волынского и житомирского Антония (Храповицкого) в Исаакиевском с соборе Петербурга 20 февраля 1905 г. была непосредственным откликом на Манифест. Показана его связь с другими выступлениями епископа Антония (Храповицкого), с текстом Высочайшего Манифеста 18 февраля œ 1905 г. и некоторыми газетными публикациями февраля 1905 года. В этой проповеди преосвященный Антоний дал оценку беспорядков в Петербурге 9/22 января 1905 года. Рассмотрены нападки в периодической печати на Слово со стороны симпатизирующих антигосударственному «освободительному движению» литераторов и указаны их причины.

Ключевые слова: 9 января 1905 г., Антоний Храповицкий, С.Н. Булгаков, В.В. Розанов, Д.С. Мережковский, освободительное движение, пропаганда.
\end{abstract}


В 1905-1907 гг. высказанное публично и в периодической печати отношение к событиям 9/22 января 1905 г. в Петербурге было важным индикатором общественно-политической позиции их авторов.

«Слово о Страшном суде и о современных событиях» епископа волынского Антония (Храповицкого) является ценным свидетельством эпохи. Слово было произнесено в воскресенье 20 февраля (5 марта) 1905 г., в неделю Страшного суда в кафедральном Исаакиевском соборе Петербурга.

Митрополит Антоний (Храповицкий) был одной из видных фигур в истории России и Православной Церкви начала XX века [45]. «Слово о Страшном суде» вскользь упоминалось советскими историками, иногда с вырванными из контекста цитатами, как пример отношения православной церкви к событиям 1905 года [43, с. $179 ; 30$, с. $131 ; 10$, с. 54].

Сразу после опубликования Слова в газете «Московские Ведомости» с нападками на епископа Антония выступили С.Н. Булгаков, В.В. Розанов и Д.С. Мережковский, участвовавшие в проходивших в Петербурге в 1901-1903 гг. религиозно-философских собраниях. В имеющихся работах «полемика» с Антонием (Храповицким) обсуждается в свете общефилософских взглядов этих литераторов $[6 ; 38$, с. $20-23]$. При этом мало внимания уделяется самому Слову и не рассматриваются мотивы произнесения Слова, что делает неполным анализ реакции на Слово.

Если принять во внимание конкретные обстоятельства и временные рамки произнесения Слова и рассматривать его в контексте текущих событий 1905-1906 гг., то это позволяет по-новому взглянуть как на цели произнесения Слова, так и на причины нападок на Слово в периодической печати со стороны либеральных литераторов.

Преосвященный Антоний (Храповицкий) периодически обращался к важным событиям в жизни империи. В окружном послании к епархиальному духовенству Волыни в 1902 г. он вспомнил недавние крестьянские беспорядки в Харьковской и Полтавской губерниях: «Последние произошли, вследствие наивной доверчивости простодушных малороссов к хитро обдуманному извету врагов нашего отечества» [32, с. 1233]. В произнесенном осе- нью 1904 г. слове «Что значит любить Россию» Антоний говорил о столичной либеральной прессе, имея в виду так называемую банкетную кампанию: «И как далека эта беззаветная преданность Отечеству, Царю и присяге от всех тех праздных речей о правах и гарантиях; о доверии и недоверии, о разных свободах и несвободах, - от этих совершенно чуждых нашей народной жизни заграничных рамок, в которые нас хотят втиснуть журналисты, как будто страна наша есть завоеванная, как будто правительство есть чуждое земле нашей учреждение» [33, с. с. 1843]. Многие мотивы, присутствующие в слове «Что значит любить Россию», впоследствии были развиты преосвященным Антонием в Слове о Страшном суде.

4/17 февраля 1905 г. в Кремле был убит Сергий Александрович. Современникам это убийство напомнило о гибели Александра II [25, с. 3]. Об обстоятельствах убийства Сергия Александровича подробно сообщал в письме в английское посольство в Петербурге консул Великобритании в Москве. На месте преступления через пять минут после взрыва оказался британский офицер, который и доложил об увиденном консулу [48, p. 41].

Первым о готовящемся убийстве Cергия Александровича написал в январе 1904 г. выходивший в то время в Париже революционный журнал «Освобождение», объявив это происками русской полиции. В заметке «Московские вести» сообщалось: «Здесь много говорят о каком-то таинственном господине, “выше среднего роста с бледным лицом", якобы приехавшем сюда с целью убить московского генерал-губернатора Сергия. Этот слух пущен самой полицией < ..>» [29, с. 295]. Сообщения об убийстве Сергия Александровича появились в европейских газетах среди новостей из России сразу после 9/22 января 1905 года [50, p. 1; 52, p. 7].

Когда убийство Сергия Александровича действительно произошло, оно было объявлено английскими газетами местью за события 9/22 января 1905 г. в Петербурге [53, р. 9]. В интервью «Манчестер Гардиан» редактор выпускавшегося в Лондоне Обществом друзей русской свободы журнала «Free Russia» Д.В. Соскис отметил, что новость об убийстве не стала неожиданностью ни для него, 
ни для тех, кто знаком с положением дел в России [53, р. 9]. П.Б. Струве поддерживал контакты с «Free Russia» [49, p. 24].

18 февраля (4 марта) 1905 г. Николаем II были подписаны и на следующий день обнародованы несколько документов, из которых наиболее важным был Высочайший манифест $[25$, с. 1]. Публикация Манифеста в день отмены крепостного права символически подчеркивала преемственность политики реформ, начатых царем-освободителем.

К этому времени царю и правительству стало очевидно, что Россия имеет дело с подготовленным и организованным антигосударственным движением. В Манифесте было упомянуто злодейское покушение на Сергия Александровича, а внутренние беспорядки увязаны с русско-японской войной: «В то время, когда доблестнейшие сыны России, с беззаветной храбростью сражаясь, самоотверженно полагают жизнь свою за веру, Царя и Отечество, - в самом Отечестве нашем поднялась смута на радость врагам нашим и к великой сердечной Нашей скорби.

Ослепленные гордынею злоумышленные вожди мятежного движения дерзновенно посягают на освященные Православной Церковью и утвержденные законами основные устои Государства Российского, полагая, разорвав естественную связь с прошлым, разрушить существующий государственный строй и, вместо оного, учредить новое управление страною на началах, Отечеству Нашему несвойственных».

Царь призвал подданных к усилению бдительности и выполнению служебного долга и напомнил, что внутреннее спокойствие необходимо как для успеха намеченных реформ, так и для успешного ведения навязанной России войны: «Но внутренние настроения последего времени и шатания мысли, способствовавшие распространению крамолы и беспорядков, обязывают Нас напомнить Правительственным Учреждениям и Властям всех ведомств и степеней долг службы и веления присяги и призвать к усугублению бдительности по охране закона, порядка и безопасности, в строгом сознании нравственной и служебной ответственности перед Престолом и Отечеством. < ..> Мы призываем благомыслящих людей всех сословий и состояний $<\ldots>$ соединиться в дружном содействии Нам словом и делом во святом и великом подвиге одоления упорного врага внешнего, в искоренении в Земле нашей крамолы и в разумном противодействии смуте внутренней, памятуя, что лишь при спокойном и бодром состоянии духа всего населения страны возможно достигнуть успешного осуществления предначертаний Наших, направленных к обновлению духовной жизни народа, упрочению его благосостояния и усовершенствованию государственного порядка».

Одновременно Высочайшим рескриптом на имя министра внутренних дел было объявлено о подготовке к созыву законодательного собрания [25, с. 1]. Попыткам разрушения существующего порядка противопоставлялась политика эволюционного преобразования государственного устройства.

На Манифест 18 февраля откликнулись газеты. «Новое Время» отмечало:

«Накипь смутных дней, наступивших на Руси, изобилует не столько русскими людьми, сколько всякой международной сволочью, от которой пора освободить смиренных русских тружеников. <..> И мы убеждены, что честный голос, доброе слово, мысль здравая пробьют себе путь в сердца и умы рабочих. Они сами отойдут от паршивых овец, от изменников родины» [27, с. 3].

В феврале 1905 г. епископ Антоний (Храповицкий) присутствовал в Святейшем Синоде в Петербурге и, очевидно, получил сведения о том, что происходило в столице 9/22 января 1905 года. В воскресенье 20 февраля (5 марта) 1905 г., в церквях проходили традиционные в начале XX в. молебствия в память об отмене крепостного права [26, с. 4].

Сравнение текста проповеди Антония (Храповицкого) с текстом Манифеста 18 февраля 1905 г. показывает, что «Слово о Страшном суде» было непосредственным откликом на Манифест. Говоря об «освободительном движении», Антоний напомнил о беспорядках в Петербурге 9-11 января 1905 г.: «Исполненные исконною злобой, ненавистью ко всему русскому, руководители этого движения не останавливаются ни пред чем, чтобы такою же злобой исполнить сердца юношей-студентов и тех слоев простолюдинов, которые могут быть доступны их влиянию. Пользуясь 
легкомысленной неопытностью одних и обманывая других чрез разного рода переодетых самозванцев, они влекут их к участию в уличных беспорядках, под пули и плети, имея в виду лишь ту единственную цель, чтобы потом кричать о строгой расправе начальства и поселять озлобление против Правительства» $[18$, c. $2 ; 34$, c. 455$]$.

Упоминание о «переодетых самозванцах» - это указание на то, что революционеры обманом вывели петербургских обывателей на улицы столицы 9/22 января 1905 года. К моменту произнесения Слова стала очевидна цель организации студенческих беспорядков в Петербурге и Москве, начавшихся осенью 1904 г. и продолженных в феврале 1905 года. Антоний также имел в виду согласованную пропагандистскую компанию на тему зверств режима.

Антоний предостерегал против революционеров: «...будем умножать свои молитвенные воздыхания о том, чтобы Он не попустил простому русскому народу заразиться общественным омрачением, - чтобы народ продолжал ясно сознавать, кто его враги и кто его друзья, чтобы он всегда хранил свою преданность Самодержавию, как единственной дружественной ему высшей власти, чтобы народ помнил, что, в случае ее колебания, он будет несчастнейший из народов, порабощенный уже не прежним суровым помещикам, но врагам всех священных ему и дорогих ему устоев его тысячелетней жизни, - врагам упорным и жестоким, которые начнут с того, что отнимут у него возможность изучать в школах Закон Божий, а кончат тем, что будут разрушать святые храмы и извергать мощи святых угодников Божиих, собирая их в анатомические театры» [18, с. 2; 34, с. 455].

Это место проповеди стало причиной, почему в изданном Русской зарубежной церковью в Нью-Йорке в 1957 г. жизнеописании Антония (Храповицкого) Слову был дан заголовок «Обличение революции и пророчество об ужасах коммунизма» [9, с. 160-165], связанный с риторикой времен холодной войны.

Антоний подчеркивал, что целью «освободительного движения» является развал России, которая «перестала бы существовать как целостное государство, ибо, лишенная своей единственной нравственно-объединяющей силы, она распалась бы на множество частей, начиная от окраины и почти до центра $<$...> Такого распадения нетерпеливо желают наши западные враги, вдохновляющие мятежников, чтобы затем, подобно коршунам, броситься на разъединенные пределы нашего Отечества, на враждующие его племена и обречь их на положение порабощенной Индии и других западно-европейских колоний» [18, c. $2 ; 34$, c. 455$]$. Этот параграф не попал в американское издание 1957 года [9, с. 160-165].

Здесь в завуалированной форме содержится указание на то, откуда идет поддержка «освободительного движения» - из Великобритании. Преосвященный Антоний (Храповицкий) напоминал, что речь идет о защите суверенитета и территориальной целостности России.

Эта часть Слова перекликается с опубликованной 16 февраля/1 марта 1905 г. в «Новом Времени» статьей «Английское сочувствие»: «И вот этой-то русской революции ждут не дождутся гг. англичане. Они смакуют ее на все вкусы, щелкают зубами, нанюхивая добычу, и с восторгом потирают руки. Но они живут в Европе, они друзья угнетенных, ничто гуманное им не чуждо, им вид крови противен, они закрывают глаза от ужаса и одним уголком смотрят с надеждой на заголовки телеграм. $<. .>$ Еще бы! Ждут гибели громадного государства. Это ли не interesting?» [24, с. 13].

В связи с этим представляет интерес свидетельство Вильяма Стэда. Стэд был известным журналистом и издателем журнала «Review of Reviews». Стэд приехал в Россию в конце августа 1905 г. и 1 (14) сентября был принят царем [31, с. 1]. Стэд пробыл в России до 27 октября (9 ноября) 1905 года [47, p. 18].

В номере «Review of Reviews» за октябрь 1905 г., когда Стэд еще был в России, появилась его статья под заголовком «Письма из России. I». В этом письме имеется фрагмент о событиях 9/22 января 1905 г.: «Допустим, <...> что двести тысяч рабочих, которые занимают такое место в воображении мистера Перриса и его друзей, смогли бы захватить Петербург...» [56, p. 373-374]. Упомянутый Стэдом Джордж Перрис был одним из активных деятелей английского Общества друзей русской свободы, на которое намекает Стэд. Здесь речь идет о том, что беспорядки 9/22 января 1905 г. были неудачной попыткой восстания. 
После возвращения Стэда в Англию 20 ноября 1905 г. Таймс напечатала его письмо редактору Таймс. В письме Стэд рассказывает об отношении в Петербурге к беспорядкам января 1905 г.: «...очень широко распространено убеждение, что революционное движение в основном финансируется англичанами и управляется из Лондона. Когда я в петербургском обществе смеялся над этими нелепыми обвинениями, мне важно говорили, что я ошибаюсь, что Англия оплачивала январских мятежников, и что англичане финансировали забастовку» $[57$, p. 10].

$\mathrm{B}$ соответствии с существовавшей практикой, текст проповеди Антония (Храповицкого), как представляющий общероссийский интерес, был опубликован в «Церковных Ведомостях» [34, с. 451-458]. Дополнительное общественное звучание Слову придала его публикация «Московскими Ведомостями» 2/15 марта 1905 года [18, с. 1-2]. Одновременно с публикацией Слова, в «Московских Ведомостях» была напечатана статья “468-ми московским дамам". Статья подписана псевдонимом Просто-Русский [18, с. 1-2; 19, с. 3]. Просто-Русский вспомнил и о 9/22 января 1905 г.: «Кто вел рабочих во время их манифестации к дворцу и нес подложно составленную, исходящую якобы от рабочих, петицию? Часть той же молодежи» [19, с. 3].

Об этом же через несколько лет сказал о. Иоанн Восторгов. 22 декабря 1908 г. в церкви Епархиального дома в Москве митрополитом Владимиром (Богоявленским) была отслужена панихида по о. Иоанну Кронштадтскому. Тогда о. Иоанн Восторгов произнес слово «Божие дитя. Памяти о. Иоанна Кронштадтского». Вспоминая об отношении Иоанна Кронштадтского к «освободительному движению», Иоанн Восторгов отмечал, что «между отцом Иоанном и лицемерными пособниками и творцами русской революции, готовыми ссылаться в свое оправдание и для достижения преступных целей на все авторитеты мира, поднявшими даже иконы и церковные хоругви под водительством преодетого в священные ризы крамольника, - не было и нет ничего общего» [35, с. 14; 7, с. 778-779].

Если доверять воспоминаниям английского дипломата Брюса Локкарта, то в сентябре 1918 г. Я.Х. Петерс счел нужным по- казать ему, как о. Иоанна (Восторгова) выволакивают из внутренней тюрьмы ВЧК на казнь [51, p. 329].

Публикация Слова «Московскими Ведомостями» и вызвала нападки в либеральной прессе. Именно после публикации на него обратили внимание С.Н. Булгаков и В.В. Розанов, которые уже выступали в печати в связи с событиями 9/22 января 1905 года.

О событиях 9/22 января 1905 г. писал журнал «Вопросы Жизни», в котором активно печатался С.Н. Булгаков. Первый номер «Вопросов Жизни» за 1905 г. был дозволен цензурой 5 февраля 1905 года. В этом номере помещена статья «9-е января 1905 г.», подписанная инициалами Г. Ш. [4, с. 329-337]. Вероятно, это был редактор либеральной газеты «Слово» Георгий Николаевич Штильман (1877-1916), печатавшийся в «Вопросах Жизни». В этой статье были воспроизведены все основные положения версии событий 9/22 января, почерпнутые из англо-французских газет:

«О предположениях "к усовершенствованию государственного порядка" <...> немыслимо говорить, пока не учтено, хотя бы в общих только чертах, значение этого страшного дня, навсегда отныне вписанного в кровавую летопись русского освободительного движения» [4, с. 329].

С.Н. Булгаков в этом номере написал следующее: «Читатель ждет от нас отклика на то, что всех терзает, волнует, жжет, о чем хочется кричать, стонать, благославлять, проклинать... Но не донесется до тебя нашего отклика, читатель. Нам остается только послать тебе, вместо гражданского отклика, глухой стон, из которого ты узнаешь, как болит и изранена писательская душа, скорбью сугубой - не только гражданской, общероссийской, но и мукой несказанного слова» [4, с. 317].

В 1901-1903 гг. С.Н. Булгаков вел двойную игру. Одновременно с участием в религиозно-философских собраниях в Петербурге он переписывался с находившимся за границей П.Б. Струве, печатал в 1902 г. под псевдонимом в «Освобождении» статьи о вреде православия и самодержавия, посещал Струве в Штутгарте в 1903 году [2, с. 514-532; 12, с. 51-52].

Другой участник религиозно-философских собраний, В.В. Розанов, в 1901-1903 гг. 
выступал с нападками в периодике на Общество распространения религиозно-нравственного просвещения и лично на руководителя этого Общества о. Философа Орнатского [44, c. 49-50].

14/27 января 1905 г. Святейший Синод написал послание по поводу событий 9-11 января 1905 г. в Петербурге [21, с. 5]. После публикации послания Синода часть столичной прессы обвинила петербургское духовенство в бездействии в день 9/22 января 1905 года.

«Новое Время» перепечатало из «СанктПетербургских Ведомостей» выдержки из статьи по поводу послания Синода. «СанктПетербургские Ведомости» приводили следующую цитату из Дневников князя Мещерского: «А для митрополита разве десятки тысяч рабочих, смущенных и сбитых с толку, - не овцы его стада, и разве пастырь этого стада не знал и не верил, что он мог и должен был прийти к ним и словом любви и правды остановить стадо на пути гибели и обличить проповедников лжи и ненависти?».

В ответ на эти сообщения 19 января (1 февраля) 1905 г. «Новое Время» поместило письмо П. Тихомирова, секретаря митрополита с.-петербургского Антония (Вадковского), с объяснениями [40, с. 2 ; 22 , с. $5 ; 23$, с. 4].

B.В. Розанов по поводу послания Синода написал статью «Будьте справедливы». Место и дата газетной публикации неизвестны, но эта статья была включена В.В. Розановым в вышедший в 1910 г. сборник [37, c. 57-61].

В статье В.В. Розанова письмо Тихомирова в «Новое Время» цитируется, как мнение митрополита петербургского Антония (Вадковского). Для достижения большего эффекта В.В. Розанов переписал князя Мещерского следующим образом: «Кн. Мещерский резко спросил в "Гражданине": отчего митрополит с.-петербургский Антоний не появился 9 января среди рабочих на площади Зимнего дворца, чтобы успокоить их, сказать им вразумительное слово? Секретарь митрополита, или, раскрыв скобки, сам митрополит через секретаря своего ответил: "В сферу политических и социальных движений духовную власть никто не считает нужным посвящать. Поэтому пастырского слова владыки к рабочим не могло и быть. Во всяком обществен- ном движении надо быть вполне осведомленным, чтобы вовремя явиться, где нужно, и сказать то, что следует"» [37, с. 57].

Цитата из письма Тихомирова в «Новое Время» Розановым приведена точно, но эта цитата не относится к тому пассажу, который приписан Розановым Мещерскому. Передергивание цитат нужно была Розанову для того, чтобы выдать свой вариант осуждения властей: «На площадь Зимнего дворца 9 января должен и мог бы выехать или выйти, для увещания рабочих и приведения им соответствующих текстов “от Писания” и вообще, чтобы они послушались “голоса матери своей св. Церкви”, обер-прокурор Святейшего Синода, или, за его престарелостью, товарищ обер-прокурора, неутомимо-деятельный и привыкший произносить “слово" В. К. Саблер» [37, с. 57].

Вслед за Розановым некоторые современные историки цитируют слова из письма П. Тихомирова как слова самого митрополита Антония (Вадковского) [45, с. 309].

В.В. Розанов первым отреагировал в периодике на Слово епископа Антония (Храповицкого), опубликовав 9/22 марта 1905 г., ровно через два месяца после январских беспорядков, в «Новом Времени» статью «Воздыханцы». В 1906 г. Розанов поместил эту статью, с минимальной стилистической правкой, в сборник «Около церковных стен» [28, c. $3 ; 36$, с. 395-400].

Чтобы опубликовать статью, В.В. Розанов пошел на ряд ухищрений. Выбрал ничего не говорящее название «Воздыханцы» и первые два абзаца статьи посвятил воздыханиям. Далее В.В. Розанов перешел к тому, ради чего была написана статья: «Это - помещенное в № 60 "Москов[ских] Ведом[остей]" "Слово о Страшном Суде и о современных событиях" одного из наших южно-русских епископов. О нем, сейчас же после появления в газете, заговорили в Петербурге и, как я слышал, очень видные литераторы собираются на него возражать. В газетах уже появились именно возражающие заметки об этом в некотором смысле достопамятном “Слове"» [36, с. 395-396].

О каких «возражающих заметках» идет речь? За два дня до публикации Розанова, в понедельник, 7/20 марта 1905 г., в либераль- 
ной газете «Слово» появилась статья «На злобу дня» [41]. Статья была подписана священником Александром Смирягиным, и эту статью тут же стали цитировать другие либеральные газеты [39, с. 1]. Редактор «Слова» Г.Н. Штильман печатался в связанном с деятелями религиозно-философских собраний журнале «Вопросы Жизни». Смирягин начинает статью так: «Православные епископы и другие весьма почтенные люди устно и в печати призывают «всех истинно-русских людей на защиту существующего порядка». Далее Смирягин со ссылками на Священное Писание высказывает решительное несогласие с такой постановкой вопроса. По тексту статьи можно понять, что объектом возмущения Смирягина было Слово о Страшном суде.

Как и Смирягин, Розанов имя епископа не указал, чтобы не привлекать лишнего внимания. Розанов же объявил, что будут и другие возражения против Слова. В.В. Розанов обвинил епископа во лжи: «...как можно согласиться например с неверной хронологией или с приписанием Наполеону Каталаунской битвы? Тут наша робость отваживается на возражения. Равно нельзя сказать, чтобы политические и общественные дела, напр[имер] хоть Земский Собор, толки о котором кажется вызвали достопамятное "Слово”, были приурочены к специальному епископскому ведению или “досмотру”» [36, с. 396].

Вряд ли Розанов успел забыть про Манифест 18 февраля 1905 года. В том номере «Нового Времени», где был опубликован Манифест, ему принадлежит статья «18 февраля»: «18-му февраля решительно суждено стать священным годовым днем русского народа, русской истории. $<\ldots>$ Сегодня для нас как день св. Пасхи. Такой же радостный день в политическом отношении» $[25$, с. 4$]$.

Поскольку связь Слова и Манифеста была ясна современникам, то нападки на Слово были для либеральных литераторов безопасным способом выразить свое несогласие с Высочайшим Манифестом. К тому же иерархи Церкви публикациями в светской печати не интересовались и в полемику с ней не вступали.

Далее Розанов осудил предостережение Антония (Храповицкого) о том, что «освобо- дительное движение» может привести к тому, что в школах запретят преподавание религии, будут разрушаться храмы и выставляться на показ мощи святых. Осудил Розанов и высказывание Антония о том, что целью революционеров является развал России. Сказав главное, до конца статьи Розанов вернулся к рассуждениям о воздыханиях, защите врачей и учителей от нападок мракобесов и т. д.

В книжной версии 1906 г. Розанов был более откровенен, и включил в сборник полный текст «Слова» с указанием имени Антония (Храповицкого), времени и места произнесения проповеди [36, с. 401-409].

В издании 1906 г. то место «Слова», где упомянуты «переодетые самозванцы», В.В. Розанов снабдил примечанием: «Намек на 9-е января 1905 г., только-что совершившееся, с небольшим за месяц перед произнесением “Слова"» [36, с. 405]. Это подтверждает, что главной причиной написания «Воздыханцев» была необходимость обозначить свою позицию по осуждению официальной версии событий 9/22 января 1905 года.

Следующим по поводу Слова высказался С.Н. Булгаков. В мартовском номере журнала «Вопросы Жизни» за 1905 г. вышла его статья «Без плана». Это был общий заголовок для эссе Булгакова, выходивших в «Новом Пути» и «Вопросах Жизни» [5, с. 388-414]. Если в январском номере «Нового Пути» С.Н. Булгаков жаловался читателям на то, что «писательская душа» может издать только «глухой стон», то Слово Антония (Храповицкого) дало ему повод высказаться членораздельно. В отличие от Розанова, Булгаков называет имя епископа волынского Антония. Булгакова ужасали те же места из Слова, что и Розанова. Булгаков приводит цитату из Слова, в которой речь идет о событиях 9 января 1905 г., и переходит к осуждению: «“Пули и плети" со стороны начальства христианский епископ считает нормальной, естественной реакцией со стороны христианского правительства. Он видит здесь только “неизбежную строгую расправу правительства”. И это не официальная отписка по долгу службы и положения, какою можно считать "послание" синода, это добровольная, никем не вынужденная проповедь, санкционирующая “законность и неизбежность” “пуль и плетей” для 
расправы с народом. Где теперь дух твой, св. Филипп Московский, беспощадный обличитель опричнины и самовластия?» Далее С.Н. Булгаков возмутился «фантазией» Антония о разрушении храмов и извержении мощей $[5$, с. 404 405]. Самовластье было у либералов традиционным эвфемизмом для самодержавия.

Последним в этой кампании принял участие известный в то время писатель Д.С. Мережковский. Этот эпизод деятельности Д.С. Мережковского неоднократно описывался исследователями [11, с. 215-216].

Епископ Никон (Рклицкий) в жизнеописании Антония Храповицкого отмечал: «Эта проповедь владыки Антония, произнесенная им в столице, привлекла к себе общее внимание и встретила резкий отпор в оппозиционной печати. С обличительной статьей против владыки выступил Мережковский, стяжавший себе тогда литературное имя: он обвинил владыку в том, что владыка будто бы натравливает простой русский народ на русскую интеллигенцию» [9, с. 165].

При этом упускается из виду, что хронологически активность Д.С. Мережковского по осуждению событий 9 января 1905 г. была органичной частью антиправительственной пропаганды, которую в начале 1906 г. вела либеральная пресса в связи с кампанией по выборам в Первую Государственную Думу.

В январе 1906 г. отмечался 25-летний юбилей смерти Ф.М. Достоевского, и вдова писателя, А.Г. Достоевская, заказала Д.С. Мережковскому вводную статью для юбилейного собрания сочинений Ф.М. Достоевского. Юбилей Достоевского был использован Д.С. Мережковским как повод для произнесения антиправительственной речи. Д.С. Мережковский написал статью под заголовком «Пророк русской революции» и зачитал ее 18 февраля 1906 г. в зале Тенишевского училища в Петербурге [46, c. 89-90].

Эту статью Д.С. Мережковский писал на рубеже 1905 и 1906 гг. и вставил туда часто цитируемую характеристику 9/22 января 1905 г. с глобальными историко-философскими обобщениями: «...мы знаем, что произошло, и чем ответила власть народу, любовь отчая детской мольбе. Народоубийством, детоубийством. И в том вина - не какого-либо отдельного самодержца, а всего “православно- го самодержавия", всего “христианского государства", от Константина Великого до наших дней» [13, с. 31-32].

Речь произвела должный эффект. В письме к С.И. Смирновой от 26 мая 1906 г. А.Г. Достоевская отмечала, что «убеждения, приписанные Д.С. Мережковским моему мужу, совершенно не соответствуют истинным его убеждениям». В тот же день С.И. Смирнова записала в свой дневник, что Мережковский написал о Достоевском «так, что привел в ужас почитателей Федора Михайловича» [20, с. 273].

Мнение А.Г. Достоевской не беспокоило Д.С. Мережковского и он неоднократно издавал эту речь $[3 ; 13$, с. $3-55 ; 16$, с. 188-238].

Вскоре после речи о Достоевском, более чем через год после произнесения проповеди епископа Антония (Храповицкого), Д.С. Мережковский опубликовал статью о Слове [14, с. 137-143; 16, с. 145-151].

Путем словесной эквилибристики Д.С. Мережковский представил речь владыки Антония как осуждение всех образованных русских людей: «Простой народ должен помнить, что враги его - все образованные русские люди. Они ненавидят Россию, замышляют погубить ее» [14, с. 138].

Не обошел Д.С. Мережковский и вопрос о западных врагах: «Тогда Россия "распадется на множество частей, начиная от окраины и почти до центра". Татары казанские, крымские и кавказские разорвут ее по клочкам. На помощь татарам придут “наши западные враги, бросятся, подобно коршунам" на разлагающийся труп России и "обрекут ее на положение порабощенной Индии и других западно-европейских колоний”» [14, с. 139].

Д.С. Мережковский точно определил, что слово Антония - это голос церкви: «Он $<$ Антоний> должен был, конечно, тысячи раз взвесить слова свои, ибо, произнося их, принимал за них ответственность не только на себя лично, но и возлагал ее на церковь, коей является он, епископ Антоний, одним из высоко стоящих светильников. Не мог он не знать, что голос его будет принят за голос, идущий, ежели не от всей церкви, то, во всяком случае, из глубины церкви» [14, с. 139].

Д.С. Мережковский вспоминал о епископе Антонии (Храповицком) и позднее. В 1906-1908 гг. Д.С. Мережковский и 3.Н. Гип- 


\section{ИСТОРИЯ РОССИИ}

пиус около двух лет провели в Париже. С пребыванием Мережковского в Париже исследователи его творчества связывают активные контакты писателя с социалистами [42, с. 335 355]. Мережковский и Гиппиус были лично знакомы и много лет переписывались с известным террористом Б.Н. Савинковым [8].

В ноябре 1907 г. в Париже был выпущен сборник статей «Царь и революция» («Le Tsar et la Révolution») [54]. Д.С. Мережковский и 3.Н. Гиппиус обсуждали идею выпуска сборника во Франции с середины 1905 года. После приезда во Францию были собраны статьи и осуществлен перевод. В письме к Л. Вилькиной 10 октября 1906 г. Мережковский трезво оценивал перспективы сборника: «Мы издаем наш сборник у Perrain'a. Выйдет, должно быть, в январе. Но неизвестно, кто его здесь будет читать. Французам ничего не нужно кроме того, что у них есть» [42, с. 349$]$.

Исследователи отмечают, что сборник остался без читателя, поскольку русским он был недоступен, а французам не нужен [42, c. 349-350].

Такой подход представляется упрощенным. Французский язык был наиболее распространенным иностранным языком в России, и публика в столицах внимательно следила за французской литературой. Сборник не должен был стать бестселлером во Франции, и был рассчитан на читающих по-французски жителей империи. К тому же книги на иностранных языках было легче перевезти через русскую границу, чем революционную литературу на русском языке.

Этой же цели служил изданный в 1908 г. в Германии немецкий перевод: «Der Zar und die Revolution» [55].

Мережковский поместил в этот сборник статью «Религия и революция». В статье рефреном повторяется мысль, что царь - это антихрист [54, p. 159-160, 194; 55, S. 110, 135]. Вслед за Мережковским Гиппиус объявляла, что русская революция должна победить царизм [54, р. 283; 55, S. 194].

А чтобы не было сомнений, о каком царе идет речь, то в статье Философова «Царьпапа» содержится полный набор пропагандистских мифов о царе Николае: царь суеверен, верит в колдунов, слабый и безвольный настолько, что не может никому противоречить, и т. д. [54, p. 32-34; 55, S. 19-21]. В этой статье Философов вспомнил о епископе Антонии (Храповицком): «Антоний, епископ волынский, как и Иоанн Кронштадтский, наиболее четко выражает социальный идеал православия» [54, p. 41-42; 55, S. 25-26]. Разумеется, этот идеал Философову крайне не симпатичен.

Русский вариант статьи из парижского сборника Мережковский поместил под названием «Революция и религия» в вышедшую в 1908 г. в России книгу «Не мир, но меч». Позже эта статья была включена в полное собрание сочинений Д.С. Мережковского [15, с. 3697]. Хвалебный отзыв на статью в июне 1908 г. написал Н.А. Бердяев. Он рассказал читателям, что эта статья уже была опубликована на французском языке [1, с. 104]. Публикация в самом Париже должна была указывать на европейское признание Д.С. Мережковского и придать дополнительный вес русской публикации.

В целом русский текст соответствует французскому. В русской версии Мережковский по цензурным соображениям смягчил нападки на царя. Во французском и немецком текстах сказано, что всякий понтифик и самодержец - Антихрист, а из русского текста «самодержец» исключен [54, p. 160; 55, S. 110; 15 , с. 49]. В другом месте «царь» заменен на нейтральное «кесарь» [54, p. 241; 55, S. 167; 15 , с. 94].

Не было случайностью и то, что высказывавшиеся с осуждением Слова литераторы были участниками религиозно-философских собраний 1901-1903 годов. В связи с этим уместно привести мнение одного из активных участников религиозно-философских собраний Н.М. Минского: «В перспективе минувших лет, можно сказать, что эти собрания явились зарей и предвестием грядущего освободительного движения» $[17$, с. 242].

Можно заключить, что Слово о страшном суде и о современных событиях преосвященного Антония (Храповицкого) было непосредственным откликом на Манифест 18 февраля 1905 г. и на организованные революционерами беспорядки в Петербурге 9/22 января 1905 года. Взгляды епископа Антония полностью соответствовали правительственной оценке этих событий и позиции Святейшего Синода. Нападки С.Н. Булгакова, Д.С. Ме- 
режковского и В.В. Розанова на Слово и на епископа Антония были продиктованы их политическими взглядами и участием в антигосударственном «освободительном движении» и были частью революционной пропаганды.

\section{СПИСОК ЛИТЕРАТУРЫ}

1. Бердяев, Н. А. Духовный кризис интеллигенции / Н. А. Бердяев. - СПб., 1910. - 304 с.

2. Булгаков, С. Н. Письма к П.Б. Струве (19011903). Исследования по истории русской мысли / С. Н. Булгаков. - М. : Модест Колеров, 2004. C. 514-532.

3. Весы. - 1906. - № 2, 3/4.

4. Вопросы Жизни. - 1905. - № 1. - С. 329-337.

5. Вопросы Жизни. - 1905. - № 3. - С. 388-414.

6. Воронцова, И. В. Русская религиозно-философская мысль в начале XX века / И. В. Воронцова. - М. : Православный Свято-Тихоновский гуманитарный университет, 2008. - 424 с.

7. Восторгов, И. И. Божие дитя / И. И. Восторгов // Восторгов И. И. Полное собрание сочинений. - М., 1915. - Т. 3. - С. 773-781.

8. Гончарова, Е. И. Революционное христовство / Е. И. Гончарова // Письма Мережковских к Борису Савинкову. - СПб. : Пушкинский Дом, 2009. C. 5-88.

9. Епископ Никон. Жизнеописание блаженнейшего Антония, митрополита Киевского и Галицкого. - Нью-Йорк : Издание Северо-Американской и Канадской епархии, 1957. - Т. 2. - 352 с.

10. Зырянов, П. Н. Православная церковь в борьбе с революцией 1905-1907 гг. / П.Н.Зырянов. - М. : Наука, 1984. - 224 с.

11. Келдыш, В. А. Ф.М. Достоевский в критике Мережковского / В. А. Келдыш // Д. С. Мережковский: мысль и слово. - М. : Наследие, 1999. C. 207-223.

12. Колеров, М. А. Не мир, но меч. Русская религиозно-философская печать от «Проблем идеализма» до «Вех». 1902-1909 / М. А. Колеров. - СПб. : Алетейя, 1996. -375 c.

13. Мережковский, Д. С. Пророк русской революции / Д. С. Мережковский. - СПб. : Издание М.В. Пирожкова, 1906. - С. 1-55.

14. Мережковский, Д. С. І. Грядущий Хам. II. Чехов и Горький / Д. С. Мережковский. - СПб. : Издание М.С. Пирожкова, 1906. - 185 с.

15. Мережковский, Д. С. Революция и религия / Д. С. Мережковский // Полное собрание сочинений. - М. : Тип. Сытина, 1914. - Т. 13. - С. 36-97.

16. Мережковский, Д. С. Полное собрание сочинений / Д. С. Мережковский. - М. : Тип. И.Д. Сытина, 1914. - Т. 14. -240 с.
17. Минский, Н. М. На общественные темы / Н. М. Минский. - Издание второе. - СПб. : Тип. ова «Общественная польза», 1909. - 284 с.

18. Московские Ведомости. - 1905. - Среда, 2 (15) марта (№ 60). - С. 1-2.

19. Московские Ведомости. - 1905. - Четверг, 3 (16) марта (№ 61). - С. 3.

20. Мостовская, И. Н. Достоевский в дневниках С.И. Смирновой (Сазоновой) / И. Н. Мостовская // Достоевский. Материалы и исследования. Т. 4. - Л. : Наука, 1980. - С. 271-278.

21. Новое Время. - 1905. - Воскресенье, 16 (29) янв. (№ 10368). - С. 5.

22. Новое Время. - 1905. - Вторник, 18 (31) янв. (№ 10370). - C. 5 .

23. Новое Время. - 1905. - Среда, 19 янв. (1 февр.) (№ 10371). - С. 4.

24. Новое Время. - 1905. - Среда, 16 февр. (1 марта) (№ 10399). - С. 13.

25. Новое Время. - 1905. - Суббота, 19 февр. (4 марта) (№ 10402). - С. 1, 3, 4 .

26. Новое Время. - 1905. - Понедельник, 21 февр. (6 марта) (№ 10404). - С. 4.

27. Новое Время. - 1905. - Суббота, 26 февр. (11 марта) (№ 10409). - С. 3.

28. Новое Время. - 1905. - Среда, 9 (22) марта (№ 10420). - C. 3 .

29. Освобождение. $-1904 .-19$ янв. (1 февр.) (№ 15/16 (39/40)).

30. Платонов, Н. Ф. Православная церковь в борьбе с революционным движением в России (1900-1917) / Н. Ф. Платонов // Ежегодник Музея Истории Религии и Атеизма. - М.; Л. : Изд-во АН CCCP, 1960. - T. 4. - C. 103-209.

31. Правительственный Вестник. - 1905. - Суббота, 3 (16) сент. (№ 189). - С. 1.

32. Прибавления к Церковным Ведомостям. 1902. - 7 сент. (№ 36). - С. 1233-1240.

33. Прибавления к Церковным Ведомостям. 1904. - 13 нояб. (№ 46). - С. 1839-1845.

34. Прибавления к Церковным Ведомостям. 1905. - 12 марта (№ 11). - С. 451-458.

35. Прибавления к Церковным Ведомостям. 1909. - 3 янв. (№ 1). - С. 14.

36. Розанов, В. В. Около церковных стен / В. В. Розанов. - СПб. : Тип. Ф. Вайсберга и П. Гершунина, 1906. - Т. 2. $-497 \mathrm{c.}$

37. Розанов, В. В. Когда начальство ушло... 1905-1906 / В. В. Розанов. - СПб. : Тип. А.С. Суворина, 1910. $-426 \mathrm{c}$.

38. Росляков, Е. С. Основные аспекты восприятия архиепископа Антония (Храповицкого) представителями русской религиозной интеллигенции начала XX века / Е. С. Росляков // Вестник КГУ им. Н.А. Некрасова. Исторические науки и археология. - 2016. - № 1. - С. 20-23. 
39. Русские Ведомости. - 1905. - Четверг, 10 марта (№ 66). - С. 1.

40. Санкт-Петербургские Ведомости. - 1905.Понедельник, 17 (30) янв. (№ 9). - С. 2. (№ 87).

41. Слово. - 1905. - Понедельник, 7 (20) марта

42. Соболев, А. Л. Мережковские в Париже (1906-1908) / А. Л. Соболев // Лица: Библиографический альманах. Вып. 1. - М.; СПб. : Феникс : Atheneum, 1992. - C. 319-371.

43. Титлинов, Б. В. Православие на службе самодержавия в русском государстве / Б. В. Титлинов. - Л. : Гос. изд-во, 1924. -210 с.

44. Филимонов, В. П. Крестом отверзается небо. Священномученик Философ Орнатский. Житие и подвиги, слова и поучения / В. П. Филимонов. - СПб. : Сатис, 2015. -270 с.

45. Фирсов, С. Л. Русская церковь накануне перемен (конец 1890-х - 1918 г.) / С. Л. Фирсов. - М. : Культурный центр «Духовная Библиотека», 2002. $623 \mathrm{c}$.

46. Холиков, А. А. Дмитрий Мережковский. Из жизни до эмиграции: 1865-1919 / А. А. Холиков. СПб. : Алетейя, 2010. - 151 c.

47. Bailen, J. O. The Tsar's "Lecturer-General". W.T. Stead and the Russian Revolution of 1905. With Two Unpublished Memoranda of Audiences with the Dowager Empress Marie Fedorovna and Nicholas II. Georgia State College research paper 23 / J. O. Bailen. Atlanta, Georgia, 1969.-91 p.

48. British Documents on Foreign Affairs: Reports and Papers from the Foreign Office Confidential Print. Part I. Series A. Russia, 1859-1914 / ed. D. Lieven. University Publications of America, 1983. - Vol. 3, Russia, 1905-1906. - 340 p.

49. Free Russia. - February 1905. - P. 24.

50. Le Journal. - No 4498. - Lundi, 23 Janvier 1905. -P. 1.

51. Lockhart, R. H. B. Memoirs of a British Agent / R. H. B. Lockhart. - L. ; N. Y. : Putnam, 1932. $-355 \mathrm{p}$.

52. The Manchester Guardian. - 1905. - Friday, January 27th. - P. 7.

53. The Manchester Guardian. - 1905. - Saturday, February 18th. - P. 9.

54. Mérejkowsky, D. Le Tsar et la Révolution / D. Mérejkowsky, Z. Hippius, D. Philosophoff. Paris : Société du Mercure de France, 1907. - 283 p.

55. Mereschkowski, D. Der Zar und die Revolution / D. Mereschkowski, Z. Hippius, D. Philosophoff. - München und Leipzig : R. Piper \& Co., Verlag, 1908. - $205 \mathrm{~S}$.

56. The Review of Reviews. - October 1905. Vol. 32. - № 190.

57. The Times (London). - Monday, Nov. 20. 1905. - P. 10. - Issue 37869.

\section{REFERENCES}

1. Berdyaev N.A. Dukhovnyy krizis intelligentsii [Spiritual Crisis of the Intellectuals]. Saint Petersburg, $1910.304 \mathrm{p}$.

2. Bulgakov S.N. Pisma k P.B. Struve (19011903). Issledovaniya po istorii russkoy mysli [Letters to P.B. Struve (1901-1903). Studies on History of Russian Thought]. Moscow, Modest Kolerov, 2004, pp. 514-532.

3. Vesy, 1906, no. 2,3/4.

4. Vopsory Zhizni, 1905, no. 1, pp. 329-337.

5. Vopsory Zhizni, 1905, no. 3, pp. 388-414.

6. Vorontsova I.V. Russkaya religioznofilosofskaya mysl $v$ nachale XX veka [Russian Religious and Phylosophical Thinking of the Early $20^{\text {th }}$ Century]. Moscow, Pravoslavnyy St.-Tikhon gumanitarnyy universitet, 2008. $424 \mathrm{p}$.

7. Vostorgov I.I. Bozhie ditya [God's Child]. Vostorgov I.I. Polnoe sobranie sochineniy [I.I. Vostorgov. Complete Collection of Works]. Moscow, 1915, vol. 3, pp. 773-781.

8. Goncharova E.I. Revolutsionnoe hristovstvo [Revolutionary Christianity]. Pisma Merezhkovskikh k Borisu Savinkovu [Merezhkovskly's Letters to B. Savinkov]. Saint Perersburg, Pushkinskiy Dom, 2009, pp. 5-88.

9. Episkop Nikon. Zhizneopisanie blazhenneishego Antoniia, mitropolita Kievskogo $i$ Halitskogo [Life of Antonius, Mithropolitan of Kiev and Halich]. New York, Izdanie Severo-Amerikanskoy i Kanadskoy eparkhii, 1957, vol. 2. 352 p.

10. Zyryanov P.N. Pravoslavnaya tserkov $v$ borbe s revolutsiey 1905-1907 gg. [Orthodox Church against Revolution of 1905-1907]. Moscow, Nauka Publ., 1984. $224 \mathrm{p}$.

11. Keldysh V.A. F.M. Dostoevsky v kritike Merezhkovskogo [Merezhkovsky's Critics of F.M. Dostoevsky]. D.S. Merezhkovsky: mysl i slovo [D.S. Merezhkovsky: Thought and Word]. Moscow, Nasledie Publ., 1999, pp. 207-223.

12. Kolerov M.A. Ne mir, no mech. Russkaya religiozno-filosofskaya pechat ot "Problem idealizma" do "Vekh". 1902-1909 [Not Peace, but a Sword. Russian Religious Press from "Problems of Idealism" to "Vekhi". 1902-1909]. Saint Petersburg, Aleteya Publ., 1996. 375 p.

13. Merezhkovskiy D.S. Prorok russkoy revolutsii [Prophet of Russian Revolution]. Saint Petersburg, Izdanie M.V. Pirozhkova, 1906, pp. 1-55.

14. Merezhkovskiy D.S. I. Gryadushchiy Kham. II. Chekhovi Gorkiy [I. Coming Kham. II. Chekhov and Gorkiy]. Saint Petersburg, Izdanie M.S. Pirozhkova, 1906. $185 \mathrm{p}$.

15. Merezhkovskiy D.S. Revolyutsiya i religiya [Revolution and Religion]. Polnoe sobranie 
sochineniy [Complete Collection of Works]. Moscow, Tip. Sytina, 1914, vol. 13, pp. 36-97.

16. Merezhkovsky D.S. Polnoe sobranie sochineniy [Complete Collection of Works]. Moscow, Tip. Sytina, 1914, vol. 14. 240 p.

17. Minskiy N.M. Na obschestvennye temy [On Social Issues]. Saint Petersburg, Obschestvennaya polza Publ., 1909. 284 p.

18. Moskovskie Vedomosti, 1905, no. 60, 2 (15) March, pp. 1-2.

19. Moskovskie Vedomosti, 1905, no. 61, 3 (16) March,p. 3.

20. Mostovskaya I.N. Dostoevsky v dnevnikakh S.I Smirnovoy (Sazonovoy) [F. M. Dostoevsky in Smirnova's (Sazonova's) Diaries]. Dostoevsky. Materialy i issledovania. T. 4 [Dostoevsky. Materials and Research. Vol. 4]. Leningrad, Nauka Publ., 1980, pp. 271-278.

21. Novoe Vremya, 1905, no. 10368, 16 (29) January, p. 5 .

22. Novoe Vremya, 1905, no. 10370, 18 (31) January, p. 5 .

23. Novoe Vremya, 1905, no. 10371, 19 January (1 February), p. 4.

24. Novoe Vremya, 1905, no. 10399, 16 February (1 March), p. 13.

25. Novoe Vremya, 1905, no. 10402, 19 February (4 March), pp. 1, 3, 4.

26. Novoe Vremya, 1905, no. 10404, 21 February (6 March), p. 4.

27. Novoe Vremya, 1905, no. 10409, 26 February (11 March), p. 3.

28. Novoe Vremya, 1905, no. 10420, 9 (22) March, p. 3 .

29. Osvobozhdenie, 1904, no. 15/16 (39/40), 19 January (1 February).

30. Platonov N.F. Pravoslavnaya tserkov v borbe s revolyutsionnym dvizheniem v Rossii (1900-1917) [Orthodox Church against Revolutionary Movement in Russia (1900-1917)]. Ezhegodnik Muzeya istorii religii i ateizma [Annual Book of Museum of History of Religion and Atheism]. Moscow; Leningrad, Izd-vo AN SSSR, 1960, vol. 4, pp. 103-209.

31. Pravitelstvennyy Vestnik, 1905, no. 189, 3 (16) September, p. 1.

32. Pribavleniya $k$ Tserkovnym Vedomostyam, 1902, no. 36, 7 September, pp. 1233-1240.

33. Pribavleniya $k$ Tserkovnym Vedomostyam, 1904, no. 46, 13 November, pp. 1839-1845.

34. Pribavleniya $k$ Tserkovnym Vedomostyam, 1905, no. 11, 12 March, pp. 451-458.

35. Pribavleniya $k$ Tserkovnym Vedomostyam, 1909, no. 1, 3 January, p. 14.

36. Rozanov V.V. Okolo tserkovnykh sten [Near Church Walls]. Saint Petersburg, Tip. F. Vaysberga i P. Gershunina, 1906, vol. 2. 497 p.
37. Rozanov V.V. Kogda nachalstvo ushlo... 1905-1906 [When Authorities Were Absent ... 19051906]. Saint Petersburg, A.S. Suvorin, 1910. 426 p.

38. Roslyakov E.S. Osnovnye aspekty vospriyatiya arkhiepiskopa Antoniya (Khrapovitskogo) predstavitelyami russkoy religioznoy intelligentsiinachala XX veka [Perception of Archbishop Antonius by Russian Religious Intelligentsia]. Vestnik KGU im. N.A. Nekrasova. Istoricheskie nauki i arkheologiya, 2016, no. 1, pp. 20-23.

39. Russkie Vedomosti, 1905, no. 66, 10 March, p. 1.

40. Sankt-Peterburgskie Vedomosti, 1905, no. 9,

17 (30) January, p. 2.

41. Slovo, 1905, no. 87, 7 (20) March.

42. Sobolev A.L. Merezhkovskie v Parizhe (19061908) [The Merezhkovskys in Paris (1906-1908)]. Litsa: Bibliograficheskiy almanakh. Vyp. 1 [Faces: Bibliographic Almanac]. Moscow; Saint Petersburg, Feniks, Atheneum, 1992, pp. 319-371.

43. Titlinov B.V. Pravoslavie na sluzhbe samoderzhavya $v$ russkom gosudarstve [Orthodox Religion as Servant of Autocracy]. Leningrad, Gosudarstvennoe izd-vo, 1924. 210 p.

44. Filimonov V.P. Krestom otverzaetsya nebo. Svyashchennomuchenik Filosof Ornatskiy. Zhitie $i$ podvigi, slova i poucheniya [Cross Opens Heavens. Holy Martyr Philosoph Ornatsky. His Life, Works and Teaching]. Saint Petersburg, Satis Publ., 2015. 270 p.

45. Firsov S.L. Russkaya tserkov nakanune peremen (konets 1890-kh-1918 g.) [Russian Church on the Eve of Changes (end of 1890s - 1918)]. Moscow, Kulturnyy tsentr "Dukhovnaya biblioteka", 2002. 623 p.

46. Kholikov A.A. Dmitriy Merezhkovsky. Iz zhizni do emigratsii: 1865-1919 [Dmitry Merezhkovsky. Life before Emigration: 1865-1919]. Saint Petersburg, Aleteya Publ., 2010. 151 p.

47. Bailen J.O. The Tsar's "Lecturer-General". W. T. Stead and the Russian Revolution of 1905. With Two Unpublished Memoranda of Audiences with the Dowager Empress Marie Fedorovna and Nicholas II. Georgia State College research paper 23. Atlanta, Georgia, 1969.91 p.

48. Lieven D., ed. British Documents on Foreign Affairs: Reports and Papers from the Foreign Office Confidential Print. Part I. Series A. Russia, $1859-$ 1914. University Publications of America, 1983. vol. 3 : Russia, 1905-1906. 340 p.

49. Free Russia, February 1905, p. 24.

50. Le Journal, 1905, no. 4498, 23 Janvier, p. 1.

51. Lockhart, R.H.B. Memoris of a British Agent. London; New York, Putnam, 1932. 355 p.

52. The Manchester Guardian, 1905, 27 January, p. 7.

53. The Manchester Guardian, 1905, 18 February, p. 9.

54. Mérejkowsky D., Hippius Z., Philosophoff Dm. Le Tsar et la Révolution. Paris, Société du Mercure de France, 1907. 283 p. 


\section{ИСТОРИЯ РОССИИ}

55. Mereschkowski D., Hippius Z., Philosophoff D. Der Zar und die Revolution. München und Leipzig, R. Piper \& Co., Verlag, 1908. 205 p.
56. The Review of Reviews, 1905, vol. 32, no. 190.

57. The Times (London), 1905, iss. 37869, 20 November, p. 10.

\section{Information About the Author}

Konstantin V. Kremenetsky, PhD, Instructor, New York Film Academy, Los Angeles Campus, 3300 Riverside Drive, Burbank, California, 91505 USA, kkremenetski@gmail.com, http://orcid.org/00000002-6729-2437.

\section{Информация об авторе}

Константин Владимирович Кременецкий, $\mathrm{PhD}$, преподаватель, Нью-Йоркская киноакадемия, отделение в Лос-Анджелесе, 3300 Риверсайд Драйв, Бербанк, Калифорния, 91505, США, kkremenetski@gmail.com, http://orcid.org/0000-0002-6729-2437. 